\title{
Potential of Sorghum Varieties as Biofuel
}

\section{Muhammad Noor Ariefin, Puji Harsono, and Amalia Tetrani Sakya}

Departement of Agrotechnology, Faculty of Agriculture, Sebelas Maret University. Jalan Engineer Sutami No. 36 A Kentingan, Surakarta 57126, Indonesia

\section{ARTICLE INFO}

\section{Received}

14 March 2021

\section{Revised}

31 May 2021

\section{Accepted for Publication \\ 26 August 2021}

\section{Published}

5 November 2021

doi: 10.29244/j.agromet.35.2.108-115

\section{Correspondence: \\ Puji Harsono \\ Departement of Agrotechnology, Faculty of Agriculture, Sebelas Maret University. Jalan Engineer Sutami No. 36 A Kentingan, Surakarta 57126, Indonesia. \\ Email: pharsono61@gmail.com}

\section{This is an open-access article} distributed under the CC BY License. (c) 2021 The Authors. Agromet.

\begin{abstract}
A B S T R A C T
The downside of fossil fuels as non-renewable energy resources in Indonesia has led to invent alternative energy resources. One of alternative sources is biofuels, which are derived from organic compound that originated from plants and living creatures. Here, we used sorghum as a source of biofuels, but current knowledge of sorghum cultivation on dry land is limited. This study aims to determine the influence of sorghum genotypes on their growth and yield in a dry land, and to analyze the potential of sorghum as biofuels. This research was carried out in low land, on vertisol soil, from August to November 2020. We applied a completely randomized block design with one factor and 3 replications. Seven sorghum varieties were identified namely Numbu, Super 1, Suri 3, Keller, Kawali, Black Sorghum, and Bioguma-2. The results showed that each variety had different genetical properties leading to various growth rates in both vegetative and generative phases. Our finding revealed that Keller variety was the most productive sorghum plant as it produced the highest sugar content $\left(20^{\circ}\right.$ Brix). Also, Keller was the tallest plants $(>300 \mathrm{~cm})$ compared to other varieties. Bioguma-2 was the second, which was proven by its longest stem $(307 \mathrm{~cm})$ and high stem sap content $\left(18^{\circ} \mathrm{Brix}\right)$. Thus, we recommended the Keller and Bioguma-2 as the suitable sorghum variety to be utilized in biofuels manufacturing.
\end{abstract}

\section{KEYWORDS}

alternative energy, Duncan Multiple Range Test, genotypes, renewable resources, stage growth

\section{INTRODUCTION}

The usage of fossil fuels as the main energy sources has caused adverse impacts, mainly on environmental sectors (Barreira et al., 2017; Martins et al., 2019; Owusu and Asumadu-Sarkodie, 2016). Burning fossil fuels, such as coal, oil, and natural gas, have significantly contributed to raise level of carbon dioxide in atmosphere, which leads to global warming (Ekwurzel et al., 2017; Perera, 2018). In addition, other chemical properties released by burning fossil fuels are harmful to ecosystem (Manisalidis et al., 2020) and public health (Munawer, 2018). In terms of its production, the extraction of fossil fuel has tremendous effects on land use change (Johnsson et al., 2019). Furthermore, availability of fossil fuels in future is limited since its natural resources have been overexploited (Kirsch, 2020). This evidence of the fossil fuels has led many scientists to do research and to invent alternative energy resources.

In Indonesia, the demand of energy is continuously rising in response to population growth (Kurniawan et al., 2020). Indonesia's energy consumption in 2014 has increased about 3.1\%, with dependency on fossil energy for more than $90 \%$ of total energy resources, while renewable energy consumption was only $1.3 \%$. (BPS, 2015). To create a sustainable energy supply, Indonesia has ambitious targets to increase the renewable source providing 23\% of total primary energy supply by 2025 , and $31 \%$ by 2050 (IRENA, 2017). One of the alternative energy resources, which had been developed by government, 
is biofuels. Biofuels are fuels derived directly from living matters, also known as biomass or bioenergy. There are five best plants used in biofuel extraction, including sorghum as its form in bioethanol.

Sorghum, which is originally domesticated in Africa, become one of fifth main staple foods worldwide as its high nutrition for healthy dietary (Tasie and Gebreyes, 2020). Also, many researches revealed that sorghum has a great potency to be used as biofuel (Mathur et al., 2017; Stamenkoviç et al., 2020; Tang et al., 2018; Yang et al., 2018). Sorghums are typically drought tolerance crops (Badigannavar et al., 2018), which have fewer nutritional inputs during the cultivation (Telleng et al., 2016), but it results in high productivity (Naoura et al., 2019). These crops are well cultivated in dry land, with low annual rainfall and air temperatures regularly around $32^{\circ} \mathrm{C}$. In Indonesia, there are five provinces which become the main production of sorghum, namely Central Java, Yogyakarta, East Java, West Nusa Tenggara, and East Nusa Tenggara.

This research aims to evaluate seven sorghum superior varieties based on field experiment. The experiment results were expected to identify the most suitable variety to be cultivated as it has the highest production of bioethanol. This information can be used as a reference to raise sorghum supply for covering both food and biomass energy demand.

\section{RESEARCH METHODS}

\section{Study Area}

This research was carried out in Cabeyan Village, Bendosari District, Sukoharjo Regency, Central Java from August to November 2020. Cabeyan, which is located about $120 \mathrm{~m}$ above sea level, covers $306 \mathrm{ha}$, in which mostly used for farming (more than two third of the total). Geographically, Cabeyan is located at $07^{\circ} 43^{\prime} 02^{\prime \prime} \mathrm{S}$ and $110^{\circ} 56^{\prime} 41^{\prime \prime E}$ (Figure 1). The air temperature ranges from $23-34^{\circ} \mathrm{C}$ with a relative humidity of $77 \%$. The soil type at the research site is vertisol soil. Vertisol soil developed from limestone (Kehal and Benderradji, 2017). High clay content allows this soil to swell when it moistened whereas it shrink when dry (Debele, 2016). The unique properties of vertisols are associated with vertical mixing (pedoturbation), lateral shear, formation of cracks, slickensides, and gilgais (Kovda et al., 2016). The content of organic matter in vertisol soil is commonly around $1.54 \%$ with a $\mathrm{pH}$ ranging from 6.0 to 8.2 , and $\mathrm{N}$ total around $0.24 \%$ (Syamsiyah et al., 2017).

\section{Research Design}

The field experiment was conducted to evaluate the yield of seven superior varieties of sorghum, namely Numbu, Super-1, Suri-3, Keller, Kawali, Black Sorghum, and Bioguma-2 (Figure 2a). The seed of sorghum were obtained from Center for Food Crops. Each variety was implemented a one-factor experimental method which was arranged in a completely randomized block design with three replications. For a replication, we planted the seeds in 16 specific points following a $20 \mathrm{~cm} \times 65 \mathrm{~cm}$ planting system. The seeds were grown in a seedbed, with $25 \mathrm{~cm}$ in height and $100 \mathrm{~cm}$ in width (Figure 2b). In total, there were 336 plants, which were divided into 21 experimental blocks.

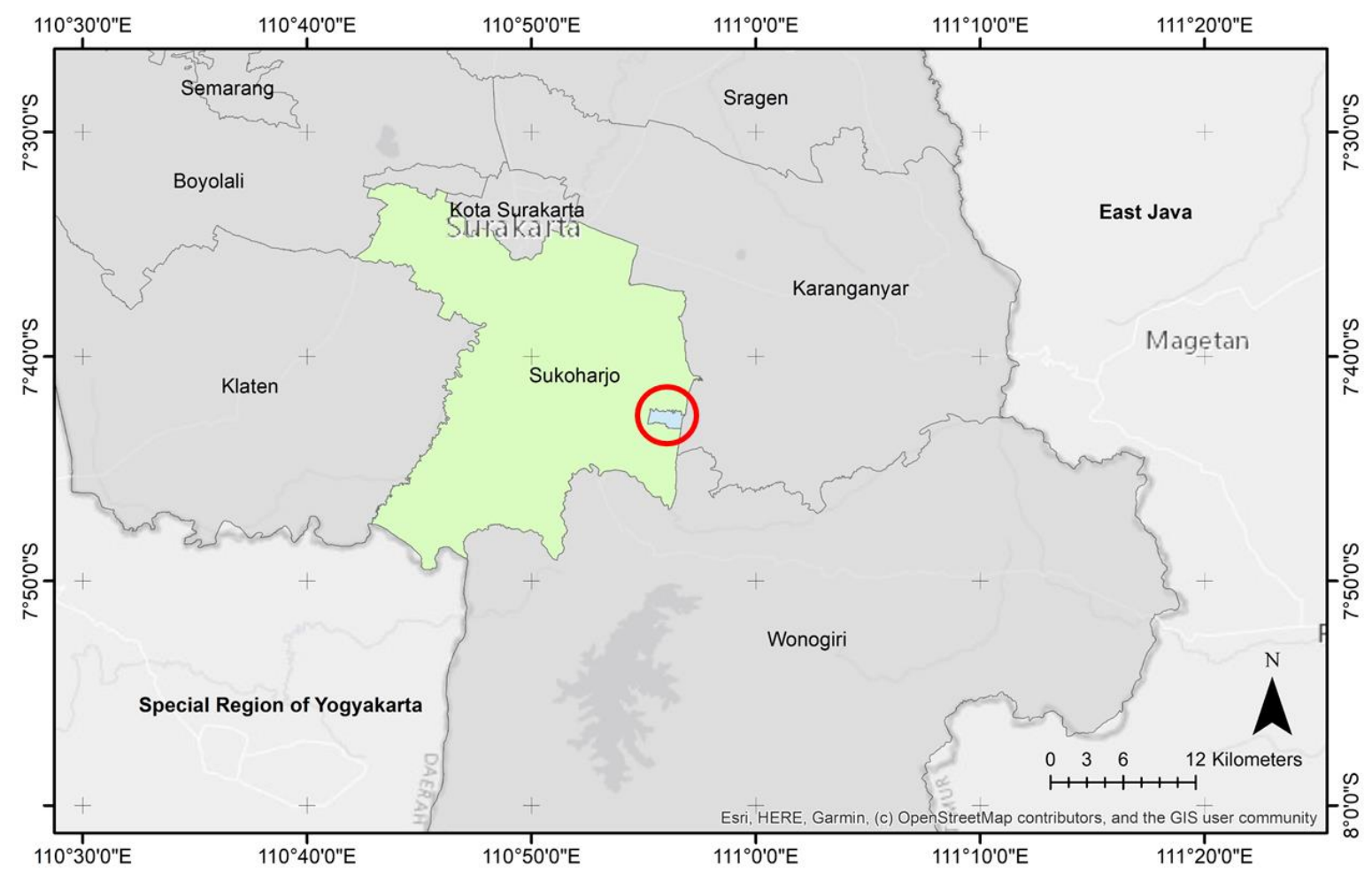

Figure 1. The location of Cabeyan village shown by the red circle. 

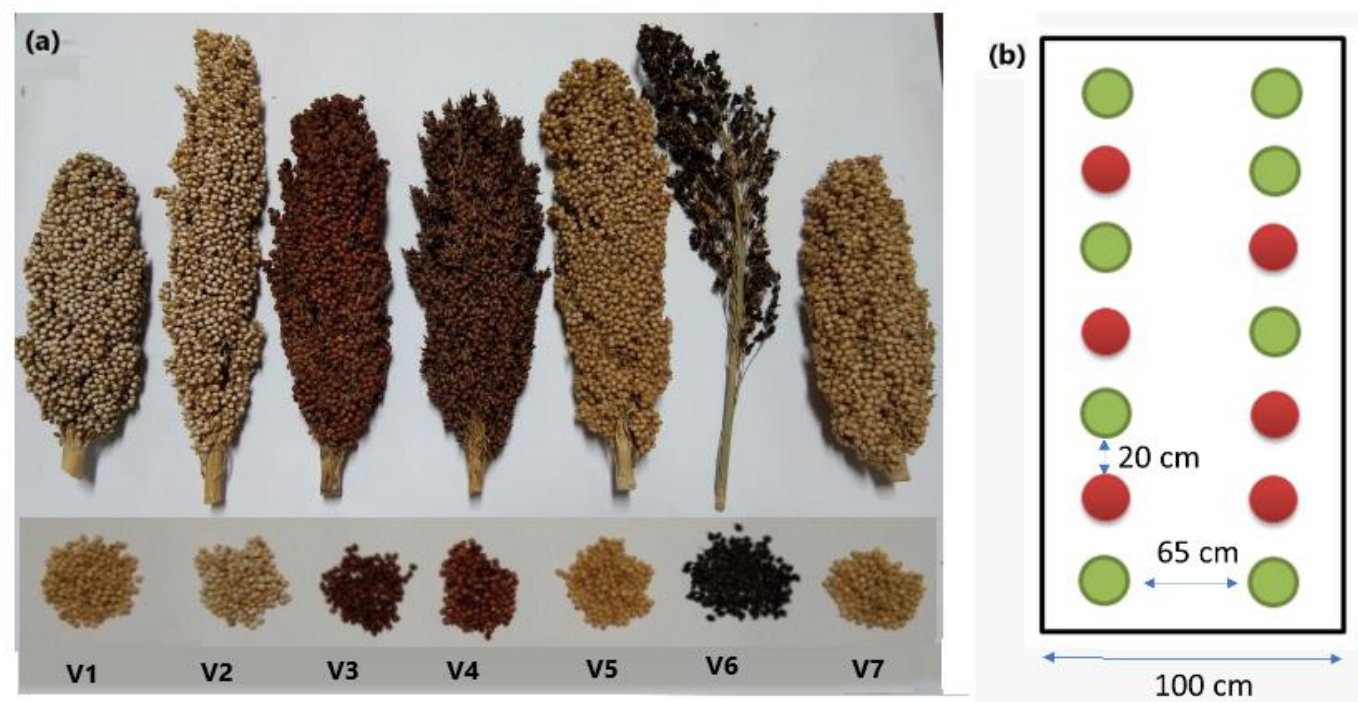

Figure 2. The materials and design of field experiment conducted in this research: (a) physical appearance of seven sorghum varieties, in order from V1 to V7: Numbu, Super-1, Suri-3, Keller, Kawali, Black Sorghum, and Bioguma-2; and (b) the planting scheme of sorghum in each seedbed. The filled circle notated the sorghum plants, while the reds are specifically taken as sample for the analysis.

Each block had same treatments as the following explanation. Some documentations depicted the field condition during the sorghum cultivation were shown in Figure 3.

- Land preparation. It is essential to plant sorghum into a weed-free seedbed, so all weeds should be controlled with tillage or a preplant burndown application prior to planting. The preparation was begun by manual clearing to remove any weeds and loosen the soil. After that, the mechanized tillage was carried out by mapping the experimental unit and creating treatment blocks.

- Seed planting. Sorghum seeds were planted four $\mathrm{cm}$ deep. Planting holes were made using tugal by following the planting system $(20 \mathrm{~cm} \times 65 \mathrm{~cm})$. We planted four sorghum seed for every hole, then we added four grains of phonska fertilizer. Lastly, the holes were refilled with manure.

- Irrigation. Sorghum requires less amount of water and has a high resistance to drought (Prasad et al., 2021). However, there are some specific times when watering should be prioritized, e.g when sorghum had grown four leaves, during the ripening period, and when the whole panicle seeds are filled up (Macêdo et al., 2018).

- Thinning. The practice of thinning sorghum plants was done to allow them plenty of growing room so that they can receive all the proper growth requirements (moisture, nutrients, light, etc.) without having to compete with other seedlings. This activity was applied after two weeks from planting day. We just allowed only one plant with the most optimum growth in each planting hole.
- Stitching plants. Since some sorghum seedlings grew abnormally, such as having withered leaves, we had to replaced them with the new sorghum seedlings.

- Regular crop maintenance. In this stage, we did some maintenance regularly to ensure that the sorghum plants grew perfectly. The maintenance practices were: (i) weeding, (ii) adding the second fertilization, and (iii) pest-disease control. The second fertilization, which was distributed between plants in each row, was urea fertilizer in dosage about one teaspoon ( $4.24 \mathrm{~g})$. To minimize potency of birds' attack toward sorghum plants, we installed flexible strimin (coarsely woven fabric used for lining) around each planting block.

- Harvest. Harvesting was done around 120 days after planting date, when the plants showed mature characteristics, such as withering and yellowing leaves, also pithy and hardening grain with a high flour content (Cox et al., 2018). The harvest process was by cutting the base of the stalk or panicle to the neck of the panicle.

\section{Plant Growth Analysis}

- Plant Height. Plant height is a growth indicator to measure the influence of environment towards plants (Li et al., 2019). The increasing plant height occur due to cell division and elongation. In this research, the height was measured from lower stem to the tip of the highest leaf or crown. This measurement was carried out when when sorghum plants were at nine weeks after planting date. There are three category to classify sorghum plant height: short $(76-150 \mathrm{~cm})$, medium $(151-225 \mathrm{~cm})$, and tall (> $225 \mathrm{~cm}$ ) (Rohila et al., 2019). 

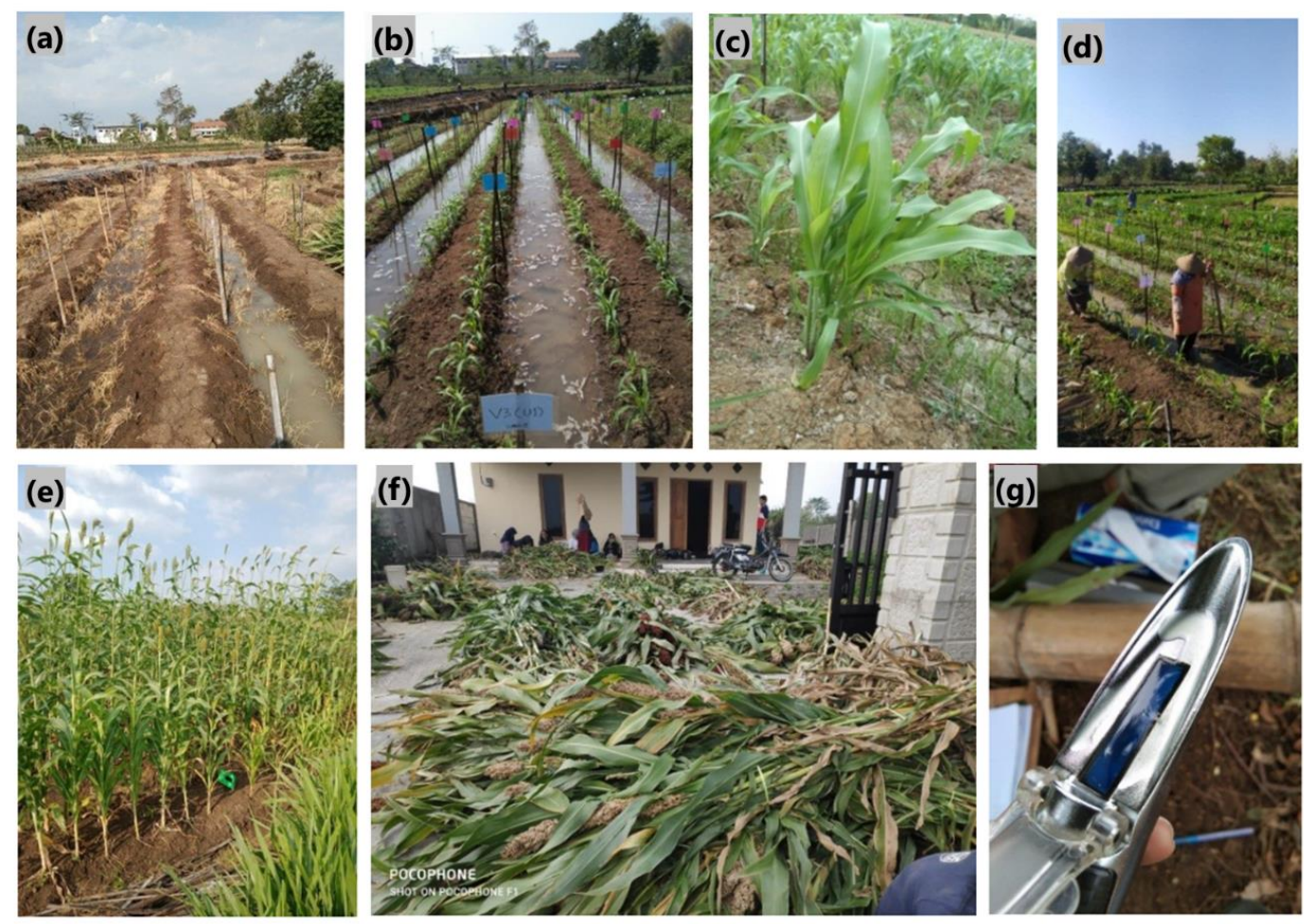

Figure 3. Documentations depicted the field condition during the sorghum cultivation: (a) field area used for this research, (b) the irrigation system of experiment area, (c) sorghum plant at 2-week after planting date, (d) crop maintenance by farmers, (e) 12-weeks of sorghum plants, (f) the harvested sorghum, and (g) the Atago hand refractometer for sugar content measurement.

- Number of leaves. Leaves are essential organs for plants as food production by photosynthesis process. This parameter was included as growth indicator of which describes the ability of plants to carry out photosynthetic activities (Zhang et al., 2020). In this research, we took the sample for calculating leaves of sorghum plant at nine weeks after planting date. Only leaves that had fully developed on the stem, were counted for this parameter.

- Stem segment length. A stem segment is a part between two nodes on the stem of sorghum plant. Unlike stem tips, the stem segment does not grow continuously. The length of the stem segment was observed by measuring the lower, middle, and upper segments using a measuring tool. This measurement was performed when the plants were 12 weeks old after planting day.

- Stem sap measurement. The sugar content in sorghum stem was measured using the Atago hand refractometer during the harvesting season (Figure $3 \mathrm{~g}$ ). The measurement process was performed by squeezing the sorghum stem until the sap dripped out into the glass of the refractometer. The sugar content was identified in Brix scale.

\section{Statistical Analysis}

From the field experiment, we collected four parameters of plant growth for each sorghum variety.
The data were then statistically analyzed using analysis of variance (ANOVA) to find out whether the experiment results were significant or not. Since the ANOVA results did not clarify which varieties were significantly different among others, the analysis was continued using Duncan's Multiple Range Test (DMRT). The DMRT was done if only the ANOVA results stated that there were significant differences between group of sorghum varieties. The Duncan's test was used a 5\% significance level for the analysis.

\section{RESULTS AND DISCUSSIONS}

\section{Plant height}

Based on sorghum plant height measurement, all varieties were included to medium and tall category, which were ranged from 181-307 cm (Table 1). There were four varieties, namely Numbu, Suri-3, Kawali, and Black Sorghum, which were belonged to medium class, while the rest were tall (more than $225 \mathrm{~cm}$ ). The two highest sorghum plants, which had no significant difference, were Bioguma-2 followed by Keller (more than $300 \mathrm{~cm}$ ). Another paired variety that had similar plant height, were Suri-3 $(214 \mathrm{~cm})$ and Black Sorghum $(220 \mathrm{~cm})$. The other varieties were varied as they notated by different letter according to the DMRT result.

The results confirmed that sorghum variety affected the diversity of plant growth. Each plant variety 
had specific ability to response the same treatment or environment given on experiment blocks. A different response led to vary the potency of yield. Compared to previous study, the resulted plant height for Numbu was far lower (30\%) than that of resulted by Cahyo et al., (2014) in Lampung, while the Keller variety was slightly higher (about 4\%). This different plant height result of the same varieties was caused by different location and the maintenance been applied to crops during the cultivation process.

\section{Number of leaves}

Based on observation in $9^{\text {th }}$ weeks after planting date, the average full-formed leaves in a plant mostly ranged from 11 to 14 leaves (Table 1). Only Black Sorghum variety that had less than 8 leaves in average. There was not a clear pattern about connection between number of leaves and plant height. Even though the highest number of leaves was observed in Bioguma-2, which also was the tallest sorghum plant in this experiment, the fewest leaves (Black Sorghum) did not indicate as the shortest plant. Based on the DMRT result, there are two pairs of sorghum varieties of which had no significant differences in average number of leaves. The first pair was Numbu and Keller varieties, which the same average value (13.89 leaves). The second pair were Super- 1 and Suri-3 with average value at 11.89 and 11.61 , respectively.

The number of leaves on a plant was mainly influenced by the genetics of the plant which control the arrangement of leaves on the stem. Our finding revealed that the higher plant did not result more leaves. The former study had explained that number of leaves were affected by environmental factor and plant growth regulators, such as air temperature, water availability, and light intensity (Qaderi et al., 2019; Zhang et al., 2020). The number of leaves increases due to the formation of new leaves (Wu et al., 2021). The higher number of leaves in a plant lead to higher biomass which was yielded (Widiastuti and Latifah, 2017).

\section{Stem segment length}

The length of stem segment in this experiment were varied between $18 \mathrm{~cm}$ and $31 \mathrm{~cm}$, as the longest and the shortest stem segment were Super-1 and Numbu, respectively (Table 1). Based on the DMRT results, from seven tested sorghum varieties, they were divided into five groups which had statistically significant different among others. It means that there were two pairs of varieties which had similar result in stem segment length. As the second longest, Keller and Black Sorghum were having similar average of stem segment length, both at nearly above $27 \mathrm{~cm}$. Furthermore, Suri-3 and Bioguma-2 were classified into same group even the Suri-3's stem segment length was one centimeter longer than that of Bioguma-2.

The results of the analysis of variance showed that the treatment of various varieties had a significant effect on the length of the stem segments. Based on previous biological study, the main factor of different in internode length was possibly due to the ability of the stem cells elongate itself (Kebrom et al., 2017). The genetic factor of each varieties considered the maximum stage of elongation phase, which mean that as stem cells reach their optimal stage, the elongation mechanism will stop (Rai et al., 2016). Previous findings suggested that stem internode length is influenced by the interaction of plant genotypes and the growing environment (Boyles et al., 2019; Hilley et al., 2016; Shukla et al., 2017). This also confirmed by Budi (2016) and Castro-Nava et al. (2016) whom their research focused to sugarcane plants, reported that varying sugarcane varieties resulted in also varying lengths of stem segments.

Table 1. Comparison the results of plant growth parameters among sorghum varieties used in this research by using Duncan's Multiple Range Test. Plant height and number of leaves were measured at nine weeks after planting date, while stem segment length and stem sap content were at 12 weeks after planting date and harvesting time.

\begin{tabular}{lcccc}
\hline \multicolumn{1}{c}{ Sorghum Variety } & Plant height $\mathbf{( c m )}$ & $\begin{array}{c}\text { Number of } \\
\text { leaves }\end{array}$ & $\begin{array}{c}\text { Stem segment length } \\
(\mathbf{c m})\end{array}$ & $\begin{array}{c}\text { Stem Sap Content } \\
\left({ }^{\circ} \text { Brix) }\right.\end{array}$ \\
\hline Numbu & $198.78^{\mathrm{d}}$ & $13.89^{\mathrm{ab}}$ & $18.22^{\mathrm{e}}$ & $16.56^{\mathrm{c}}$ \\
Super-1 & $284.50^{\mathrm{b}}$ & $11.89^{\mathrm{c}}$ & $31.89^{\mathrm{a}}$ & $17.67^{\mathrm{bc}}$ \\
Suri-3 & $214.50^{\mathrm{c}}$ & $11.61^{\mathrm{c}}$ & $24.69^{\mathrm{c}}$ & $16.94^{\mathrm{c}}$ \\
Keller & $304.78^{\mathrm{a}}$ & $13.89^{\mathrm{ab}}$ & $27.22^{\mathrm{b}}$ & $20.61^{\mathrm{a}}$ \\
Kawali & $181.61^{\mathrm{e}}$ & $13.39^{\mathrm{b}}$ & $20.23^{\mathrm{d}}$ & $9.61^{\mathrm{d}}$ \\
Black Sorghum & $220.44^{\mathrm{c}}$ & $7.33^{\mathrm{d}}$ & $27.85^{\mathrm{b}}$ & $6.67^{\mathrm{e}}$ \\
Bioguma-2 & $307.94^{\mathrm{a}}$ & $14.33^{\mathrm{a}}$ & $23.64^{\mathrm{c}}$ & $18.67^{\mathrm{b}}$ \\
\hline
\end{tabular}

Note: the same letter notation on the values in one column indicates no significant difference at $5 \%$ level $(p>0.05)$. 


\section{Level of stem sap}

Stem sap becomes an essential component of sorghum plant since it is a place where glucose is stored. Based on the measurement using refractometer at the harvesting period, the average sugar content greatly varied, which were ranged from 6 to $20^{\circ}$ Brix (Table 1). Based on the DMRT results, almost all varieties had significantly different in resulting sugar content. Only Numbu and Suri-3 were categorized into similar result in average, which nearly above $16{ }^{\circ}$ Brix. Kawali and Black Sorghum became the least productive sorghum plants since the sugar content were only a half of the others (less than $10^{\circ} \mathrm{Brix}$ ). Meanwhile, the Keller variety was the highest sugar content with the average value was around $20.6^{\circ}$ Brix.

Our finding revealed that the sugar content in the stem sap was greatly influenced by the genetic factor of each sorghum variety. This result was relevant with the research finding by Carvalho and Rooney (2017) who compared twenty sorghum varieties in Texas. In addition, the sugar content is also influenced by the climate, sorghum age, and maintenance methods (fertilizer application and irrigation) (Gerrano et al., 2014; June, 2011; Sekhon et al., 2016). However, in the sorghum generative phase, the sweetness level in the stem sap will decrease since its sucrose deposits are diverted for seed development (Sehgal et al., 2018).

\section{CONCLUSIONS}

Field experiment was conducted to assess seven sorghum varieties as its high potential on produce ethanol for biomass energy resource. We used four parameter of plant growth component, namely plant height, number of leaves, stem segment length, and stem sap content. Based on the ANOVA and DMRT analysis, in general, the tested sorghum plants mostly resulted significant differences among varieties for all parameters. The Keller and Bioguma-2 variety were concluded as the highest potential yield of sorghum plant since it had high sugar content, plant height, and stem segment length. Thus, we recommended both varieties as the suitable sorghum variety to be cultivated, especially on dryland, in order to develop highly productive biofuel in Indonesia.

\section{ACKNOWLEDGEMENTS}

This research was funded by Ministry of Research and Technology/National Research and Innovation Agency of the Republic of Indonesia. The authors thank to two anonymous reviewers for their valuable comments on the manuscript.

\section{REFERENCES}

Badigannavar, A., Teme, N., de Oliveira, A.C., Li, G., Vaksmann, M., Viana, V.E., Ganapathi, T.R., Sarsu, F., 2018. Physiological, genetic and molecular basis of drought resilience in sorghum [Sorghum bicolor (L.) Moench]. Ind J Plant Physiol. 23, 670-688. https://doi.org/10. 1007/s40502-018-0416-2

Barreira, A., Patierno, M., Bautista, C.R., 2017. Impacts of pollution on our health and the planet: The case of coal power plants. Perspect 28, 1-10.

Boyles, R.E., Brenton, Z.W., Kresovich, S., 2019. Genetic and genomic resources of sorghum to connect genotype with phenotype in contrasting environments. The Plant Journal 97, 19-39. https://doi.org/10.1111/tpj.14113

BPS, 2015. BP Stastical Review 2015: Pasar Energi Indonesia. Badan Pusat Statistik, Jakarta.

Budi, S., 2016. Test of Varieties and Breeding Seed Toward the Productivity of Sugar Cane (Saccharum Officinarum. L) on Dry Land. International Journal of Applied Environmental Sciences 11, 855-871.

Cahyo, G.D., Hidayat, K.F., Sunyoto, S., Kamal, M., 2014. Pertumbuhan dan Hasil Tiga Varietas Sorgum (Sorghum Bicolor (L.) Moench) Ratoon Pada Kerapatan Tanaman Yang Berbeda. Jurnal Agrotek Tropika 2. https://doi.org/10.23960 /jat.v2i3.2069

Carvalho, G., Rooney, W.L., 2017. Assessment of Stalk Properties to Predict Juice Yield in Sorghum. Bioenerg. Res. 10, 657-670. https://doi.org/10. 1007/s12155-017-9829-4

Castro-Nava, S., Huerta, A.J., Plácido-de la Cruz, J.M., Mireles-Rodríguez, E., 2016. Leaf Growth and Canopy Development of Three Sugarcane Genotypes under High Temperature Rainfed Conditions in Northeastern Mexico. International Journal of Agronomy 2016, e2561026. https://doi.org/10.1155/2016/ 2561026

Debele, T., 2016. Integrated Management of Vertisols for Crop Production in Ethiopia: A Review. Journal of Biology, Agriculture and Healthcare $6,26$.

Ekwurzel, B., Boneham, J., Dalton, M.W., Heede, R., Mera, R.J., Allen, M.R., Frumhoff, P.C., 2017. The rise in global atmospheric $\mathrm{CO}$, surface temperature, and sea level from emissions traced to major carbon producers. Climatic Change 144, 579 590. https://doi.org/10.1007/s10584-0171978-0

Gerrano, A.S., Labuschagne, M.T., van Biljon, A., Shargie, N.G., 2014. Genetic variability among sorghum 
accessions for seed starch and stalk total sugar content. Sci. agric. (Piracicaba, Braz.) 71, 472479. https://doi.org/10.1590/0103-9016-20130322

Hilley, J., Truong, S., Olson, S., Morishige, D., Mullet, J., 2016. Identification of Dw1, a Regulator of Sorghum Stem Internode Length. PLoS One 11, e0151271. https://doi.org/10.1371/journal. pone. 0151271

IRENA, 2017. Renewable Energy Prospects: Indonesia.

Johnsson, F., Kjärstad, J., Rootzén, J., 2019. The threat to climate change mitigation posed by the abundance of fossil fuels. Climate Policy 19, 258-274. https://doi.org/10.1080/14693062. 2018.1483885

June, T., 2011. The Effect of Light on Growth of Cassava And Sorghum I Light Distribution And Extinction Coefficient. J.Agromet 9, 35-41. https://doi.org/10.29244/j.agromet.9.2.35-41

Kebrom, T.H., McKinley, B., Mullet, J.E., 2017. Dynamics of gene expression during development and expansion of vegetative stem internodes of bioenergy sorghum. Biotechnology for Biofuels 10, 159. https://doi.org/10.1186/s13068-0170848-3

Kehal, L., Benderradji, M.E.H., 2017. Agropedological characterization of the soils in the region of Djebel El Ouahch, Constantine, Algeria. Journal of Applied Biosciences 119, 11888-11903. https://doi.org/10.4314/jab.v119i1.6

Kirsch, S., 2020. Running out? Rethinking resource depletion. Extr Ind Soc 7, 838-840. https://doi.org/10.1016/j.exis.2020.06.002

Kovda, I., Lebedeva, M., Morgun, E., 2016. Central image of Vertisols: evolution of concepts of their morphology and genesis. Dokuchaev Soil Bulletin.

Kurniawan, R., Trencher, G.P., Edianto, A.S., Setiawan, I.E., Matsubae, K., 2020. Understanding the MultiFaceted Drivers of Increasing Coal Consumption in Indonesia. Energies 13, 3660. https://doi.org/10.3390/en13143660

Li, S., Jiang, H., Wang, J., Wang, Y., Pan, S., Tian, H., Duan, M., Wang, S., Tang, X., Mo, Z., 2019. Responses of plant growth, physiological, gas exchange parameters of super and non-super rice to rhizosphere temperature at the tillering stage. Sci Rep 9, 10618. https://doi.org/10.1038/ s41598-019-47031-9

Macêdo, A.J. da S., Ramos, J.P. de F., Santos, E.M., Sousa, W.H. de, Oliveira, F.G. de, Souza, J.T.A., Oresca, D., 2018. Morphometric and productive characteristics of sorghum genotypes for forage production in the Brazilian semi-arid.
Rev. bras. saúde prod. anim. 19, 256-267. https://doi.org/10.1590/S1519-99402018000 300003

Manisalidis, I., Stavropoulou, E., Stavropoulos, A., Bezirtzoglou, E., 2020. Environmental and Health Impacts of Air Pollution: A Review. Frontiers in Public Health 8, 14. https://doi.org/10.3389/fpubh.2020.00014

Martins, F., Felgueiras, C., Smitkova, M., Caetano, N., 2019. Analysis of Fossil Fuel Energy Consumption and Environmental Impacts in European Countries. Energies 12, 964. https://doi.org/10.3390/en12060964

Mathur, S., Umakanth, A.V., Tonapi, V.A., Sharma, R., Sharma, M.K., 2017. Sweet sorghum as biofuel feedstock: recent advances and available resources. Biotechnology for Biofuels 10, 146. https://doi.org/10.1186/s13068-017-0834-9

Munawer, M.E., 2018. Human health and environmental impacts of coal combustion and postcombustion wastes. Journal of Sustainable Mining 17, 87-96. https://doi.org/10.1016/ j.jsm.2017.12.007

Naoura, G., Sawadogo, N., Atchozou, E.A., Emendack, Y., Hassan, M.A., Reoungal, D., Amos, D.N., Djirabaye, N., Tabo, R., Laza, H., 2019. Assessment of agro-morphological variability of dry-season sorghum cultivars in Chad as novel sources of drought tolerance. Sci Rep 9, 19581. https://doi.org/10.1038/s41598-01956192-6

Owusu, P.A., Asumadu-Sarkodie, S., 2016. A review of renewable energy sources, sustainability issues and climate change mitigation. Cogent Engineering 3, 1167990. https://doi.org/10. 1080/23311916.2016.1167990

Perera, F., 2018. Pollution from Fossil-Fuel Combustion is the Leading Environmental Threat to Global Pediatric Health and Equity: Solutions Exist. Int J Environ Res Public Health 15, 16. https://doi.org/10.3390/ijerph15010016

Prasad, V.B.R., Govindaraj, M., Djanaguiraman, M., Djalovic, I., Shailani, A., Rawat, N., Singla-Pareek S.L., Pareek, A., Prasad, P.V.V., 2021. Drought and High Temperature Stress in Sorghum: Physiological, Genetic, and Molecular Insights and Breeding Approaches. International Journal of Molecular Sciences 22, 9826. https://doi.org/10.3390/ijms22189826

Qaderi, M.M., Martel, A.B., Dixon, S.L., 2019. Environmental Factors Influence Plant Vascular System and Water Regulation. Plants (Basel) 8, 65. https://doi.org/10.3390/plants8030065 
Rai, K.M., Thu, S.W., Balasubramanian, V.K., Cobos, C.J., Disasa, T., Mendu, V., 2016. Identification, Characterization, and Expression Analysis of Cell Wall Related Genes in Sorghum bicolor (L.) Moench, a Food, Fodder, and Biofuel Crop. Frontiers in Plant Science 7, 1287. https://doi.org/10.3389/fpls.2016.01287

Rohila, N., Arya, S., Kumari, P., Pinki, Versha, 2019. DUS characterization of various sorghum genotypes (Sorghum bicolor L. Moench) on the basis of midrib colour. J Pharmacogn Phytochem 8, 588-595.

Sehgal, A., Sita, K., Siddique, K.H.M., Kumar, R., Bhogireddy, S., Varshney, R.K., Hanumantha, B., Nair, R.M., Prasad, P.V.V., Nayyar, H., 2018. Drought or/and Heat-Stress Effects on Seed Filling in Food Crops: Impacts on Functional Biochemistry, Seed Yields, and Nutritional Quality. Frontiers in Plant Science 9, 1705. https://doi.org/10.3389/fpls.2018.01705

Sekhon, R.S., Breitzman, M.W., Silva, R.R., Santoro, N., Rooney, W.L., de Leon, N., Kaeppler, S.M., 2016. Stover Composition in Maize and Sorghum Reveals Remarkable Genetic Variation and Plasticity for Carbohydrate Accumulation. Frontiers in Plant Science 7, 822. https://doi.org/10.3389/fpls.2016.00822

Shukla, S., Felderhoff, T.J., Saballos, A., Vermerris, W., 2017. The relationship between plant height and sugar accumulation in the stems of sweet sorghum (Sorghum bicolor (L.) Moench). Field Crops Research 203, 181-191. https://doi.org/ 10.1016/j.fcr.2016.12.004

Stamenković, O.S., Siliveru, K., Veljković, V.B., BankovićIlić, I.B., Tasić, M.B., Ciampitti, I.A., Đalović, I.G., Mitrović, P.M., Sikora, V.Š., Prasad, P.V.V., 2020. Production of biofuels from sorghum. Renewable and Sustainable Energy Reviews 124, 109769. https://doi.org/10.1016/j.rser. 2020.109769

Syamsiyah, J., Sumarno, S., Suryono, S., Rajab, N.E.M., Aryaningrum, I., 2017. The Effects of Mixed
Source Fertilizer Application on Vertisol Fertility and Growth of Mustard. JOURNAL OF TROPICAL SOILS 22, 139-148. https://doi.org/ 10.5400/jts.2017.v22i3.139-148

Tang, C., Li, S., Li, M., Xie, G.H., 2018. Bioethanol Potential of Energy Sorghum Grown on Marginal and Arable Lands. Front Plant Sci 9, 440. https://doi.org/10.3389/fpls.2018.00440

Tasie, M.M., Gebreyes, B.G., 2020. Characterization of Nutritional, Antinutritional, and Mineral Contents of Thirty-Five Sorghum Varieties Grown in Ethiopia. International Journal of Food Science 2020, e8243617. https://doi.org/ 10.1155/2020/8243617

Telleng, M., Wiryawan, K.G., Karti, P.D.M.H., Permana, I.G., Abdullah, L., 2016. Forage Production and Nutrient Composition of Different Sorghum Varieties Cultivated with Indigofera in Intercropping System. Media Peternakan 39, 203-209. https://doi.org/10.5398/medpet. 2016.39.3.203

Widiastuti, E., Latifah, E., 2017. Keragaan Pertumbuhan dan Biomassa Varietas Kedelai (Glycine max (L)) di Lahan Sawah dengan Aplikasi Pupuk Organik Cair | Jurnal Ilmu Pertanian Indonesia. Jurnal Ilmu Pertanian Indonesia 21, 90-97. https://doi.org/10.18343/jipi.21.2.90

Wu, W., Du, K., Kang, X., Wei, H., 2021. The diverse roles of cytokinins in regulating leaf development. Hortic Res 8, 1-13. https://doi.org/10.1038/ s41438-021-00558-3

Yang, X., Li, M., Liu, H., Ren, L., Xie, G., 2018. Technical Feasibility and Comprehensive Sustainability Assessment of Sweet Sorghum for Bioethanol Production in China. Sustainability 10, 731. https://doi.org/10.3390/su10030731

Zhang, P., Zhang, Z., Li, B., Zhang, H., Hu, J., Zhao, J., 2020. Photosynthetic rate prediction model of newborn leaves verified by core fluorescence parameters. Sci Rep 10, 3013. https://doi.org/ 10.1038/s41598-020-59741-6 